\title{
THE PROSPECT OF THE EXISTENCE OF NATIONAL CRIMINAL CODE IN A DEMOCRATIC STATE IN INDONESIA DURING THE COVID-19 PANDEMIC
}

\author{
Suharyo \\ Badan Penelitian dan Pengembangan Hukum dan Hak Asasi Manusia, \\ Kementerian Hukum dan Hak Asasi Manusia Republik Indonesia, Jakarta \\ Corresponding author: suharvodenkes@gmail.com \\ Received on: 21-07-2021; Revised on: 20-08-2021; Approved to be published on: 31-08-2021 \\ DOI:http://dx.doi.org/10.30641/dejure.2021.V21.285-298
}

\begin{abstract}
The Dutch colonial product Criminal Code which has been translated into various versions remains valid in Indonesia, because the plenary session of the House of Representatives of RI for the 2014-2019 period which was attended by government elements to ratify Draft Criminal Code to become the National Criminal Code was postponed due to refusal from students and civil society movements. The Covid-19 pandemic as a health and humanitarian disaster that destroyed almost all aspects of human life, throughout the world including in Indonesia with various long-lasting negative impacts, in 2020 until now has thwarted legal development including realizing the National Criminal Code. This research was conducted in a sociological juridical manner, with the issue of whether the Draft Criminal Code would be re-discussed in several articles, and then ratified by the House of Representatives of RI. How to respond to the social action reactions of a group of people who are expected to persist, even though the Draft Criminal Code is re-discussed on a limited basis, and is expected to hold demonstrations and rallies, as well as what are the prospect of the existence of the National Criminal Code in the Covid-19 pandemic era. The government continues to receive and select input or suggestions from various community groups regarding crucial issues. What is certain is that if there is a rejection of the Draft Criminal Code to be ratified, it must be returned to the constitution in force in the Unitary State of the Republic of Indonesia, namely through a judicial review lawsuit at the Constitutional Court of the Republic of Indonesia.
\end{abstract}

Keywords: National Criminal Code; democracy; Indonesia; Covid-19

\section{INTRODUCTION}

The great history of the journey of the Unitary State of the Republic of Indonesia (NKRI) to have a national product KUHP (Criminal Code), the product of the Indonesian nation itself, through the pioneering and expertise of criminal law experts and various other parties as well as members of the House of Representatives (DPR), on September 24, 2019 failed miserably.

President Joko Widodo, after receiving input and a flood of criticism from students and NonGovernmental Organizations (NGOs), asked for a delay (cancellation) of the ratification of the Draft Criminal Code due to a number of unresolved issues, which raised pros and cons in certain communities and needed to be discussed by the House of Representatives in the next period.

President Joko Widodo's legal politics, which asked for a delay in the ratification of the Draft Criminal Code, was intended to cool down the heated political situation and condition due to massive demonstrations by student groups in various cities in Indonesia, especially to welcome the inauguration of the President and Vice President on October 1, 2019, which was attended by dozens of state guests and highlighted by the international community.

The very long journey to produce the Draft Criminal Code as the product of the Indonesian nation has ended. Various legal circles and Indonesian people who have been waiting for the colonial Criminal Code to be changed to the National Criminal Code are still waiting, whether the National Criminal Code can be realized in the next 5 (five) years or forever will still use the Colonial Criminal Code, even though it is translated unofficially.

Whereas the contents of the draft Criminal Code are sourced from input and aspirations of the community through various seminars, research, conferences, workshops and so on. Part of it comes from the results of comparisons of criminal laws in other countries that are considered good 
and appropriate to use. Various developments and progress of the community have also become input for the drafters of the draft Criminal Code.

In a democracy, of course, the Draft Criminal Code has been discussed properly. Our people from various circles have voiced their opinions and criticism of the Draft Criminal Code to the drafters, to the House of Representatives and the government. It can be said that the preparation has been participatory. This is a very important thing. ${ }^{1}$

As a public law that regulates the relations between the state and its people, criminal law is considered as the main public law that must be reformed in the national law reform program. 15 (fifteen) years after Indonesian independence (1945-1960), the effort to improve the Indonesian criminal law system was still partial or patchwork, that is, it only revoked or renewed the Criminal Code. Several laws that revoked or renewed the Criminal Code after 15 years of independence include Law Number 1 Year 1946 concerning Criminal Law Regulations, Law Number 20 Year 1946 concerning the Penalty of Coverage, Law Number 8 Year 1951 concerning Suspension of Granting Permits to Doctors and Dentists, Law Number 73 Year 1958 concerning Declaring the Applicability of Law Number 1 Year 1946 for the Entire Territory of Indonesia and amending the Criminal Code Law Number 1 Year 1960 concerning Amendments to the Criminal Code, Law Number 16 Year 1960 concerning Several Amendments in the Criminal Code, Law Number 18 Year 1960 concerning Changes in the Punishment of the Number of Fines in the Criminal Code and in other Criminal Provisions. ${ }^{2}$

The drafting of the Draft Criminal Code which failed to be ratified in the Plenary Session of the House of Representatives for the last period of September 2019, had actually been prepared in an open, serious and participatory manner through a very long period of time. The Draft Criminal Code holds the highest record regarding the length of time it has been prepared. Since 1967, 1973, 1977, 1980, 1981, 1982, 1985, 1987, 1988, 1989,

\footnotetext{
Topo Santoso, "Menjadi Negeri Tanpa KUHP Sendiri," Media Indonesia, September 23, 2019, 1.

2 Badan Pembinaan Hukum Nasional, Historisitas Hukum Pidana Indonesia (Sejarah Perkembangan Pra-Pasca Kolonial Dan Usaha Pembaharuan Hukum Pidana Nasional Di Indonesia), BPHN Kementerian Hukum Dan HAM (Jakarta, 2018), 6.
}

1990, 1991, 1992, 1993, 1998, 2002, 2004, 2005, 2006, 2007, 2008, 2010, 2012, 2014, 2015. ${ }^{3}$

In the 1998/1999 Draft Criminal Code with 646 articles, and published by the Directorate of Legislation, the Directorate General of Law and Legislation, the Department of Law and Legislation in 1999/2000, according to the experience and knowledge of the researcher, 1000 (one thousand) books were sent to the Legal Bureau of Ministries/Agencies, Supreme Court of the Republic of Indonesia, Attorney General of the Republic of Indonesia, BABINKUM TNI, Polri, Senior Lawyers/Advocates throughout Indonesia, Provincial Law Bureau, Faculty of Law of State and Private Universities throughout Indonesia, Colleges of Law throughout Indonesia, all Political Parties, Members of the House of Representatives, and various other parties. As the time goes by, and with the development of advanced internet technology and so on, the dissemination of the Draft Criminal Code is no longer carried out through the printing of the Draft Criminal Code, and is replaced by these technological advances.

The follow-up to the Draft Criminal Code process will take place in the House of Representatives for the 2019-2024 period, and the 2019-2024 government period. The Ministry of Law and Human Rights plans to re-discuss the substance of a number of problematic articles in the Draft Criminal Code. However, the House of Representatives has not reached an agreement regarding the mechanism for discussing the draft legislation, which in the past period drew rejection from the community. The government has mapped 14 articles out of a total of 628 articles of the Draft Criminal Code which are considered problematic. While the National Alliance for Criminal Code Reform, which consists of civil society groups and criminal law observers, found that there are still 24 problematic points. $^{4}$

In its development, the Draft Criminal Code, which could almost be legalized into a national product Criminal Code, was included again in the Prolegnas (National Legislative Program) 2020-2024, with a priority agenda in 2020. And what needs to be underlined is that in the future the Criminal Code will be enforceable nationally, including ships and airplanes with

\footnotetext{
Ibid, 9.

4 "Pemerintah Dan DPR Berbeda Pendapat," Kompas, November 20, 2019, 1.
} 
red and white flags. Although the Draft Criminal Code is centralized, its original product collects many customary sanctions that have developed throughout the people of Indonesia, as well as the development of criminal law from the past, present and anticipating the future, including conducting comparisons of criminal law in various other countries, which are in line with the national law system.

Entering 2020, with enthusiasm and ambition, as well as Indonesia's confidence with all local wisdom, including the people's culture, the government affirmed that Covid-19 will not enter Indonesia. However, with the movement of people, goods, food, and services that always interact with foreigners, slowly and surely Covid-19 entered Indonesia. The government began to stutter, many citizens did not believe in Covid-19 and its ferocity. Medical and health experts, since the beginning, have repeatedly warned that Covid-19 will definitely enter Indonesia. Starting in March 2020, the Government only realized that Covid-19 had truly become a pandemic. The death rate continues to move up, while there is no cure for Covid-19.

Entering August 2020 to September 2020, yellow flags (symbol of death) are increasingly flying around residential areas. The flag marking the death of the residents further disturbed anyone who saw it. Six months during the Covid-19 pandemic, the yellow flag was flying like a frightening terror. Mugiyono's (41) cell phone flashes a sign that there is a WhatsApp message from the management group of the residents of Pademangan Barat Village, North Jakarta. The message reads "Innalillahi, has passed away to rahmatullah Haji Soerjono, Chairperson of the Nurul Hidayah Mosque of RW.013 at 01.55". The news that came on Sunday (6/9/2020) in the morning of Western Indonesian Time Zone seemed to break the silence of the atmosphere. ${ }^{5}$ In the course of time, the Covid-19 pandemic has caused a lot of casualties. In the next two weeks, the accumulation of Covid-19 cases worldwide which is currently 196.55 million, will reach 200 million cases. In a number of Asian countries, the spike in cases is striking. This was especially

\footnotetext{
5 "Pandemi Covid-19 Bendera Kuning Yang Makin Sering," Kompas, September 9, 2020, 1.
}

recorded this weekend. Compared to daily cases in Indonesia, the number is still much lower. ${ }^{6}$

Based on this background, several problems can be identified. First, whether the Draft Criminal Code will still be re-discussed in several articles and then ratified by the House of Representatives; Second, how to respond to the social reactions of a group of people who are certain to persist even though the Draft Criminal Code in several articles has been re-discussed, especially those who reject the ratification of the Draft Criminal Code, and what is the prospect of the existence of the National Criminal Code, even though it is currently in the Covid-19 pandemic.

\section{RESEARCH METHOD}

To answer the problem regarding the Problems of Cancelation of the Ratification of the Draft Criminal Code, this research used a sociological juridical research method. In a sociological juridical approach, law as law in action is described as an empirical social phenomenon. Thus, law is not only given meaning as an interwoven value, official decisions made up of rules and norms, written positive law, but can also be given meaning as a teaching system about reality, regular and steady behavior, or law in the sense of an officer ${ }^{7}$. The data regarding the principles of criminal law, a democratic country, the protection of human rights, the dynamics of handling Covid-19 in Indonesia, and the social reactions of the community were obtained from library research.

As a conceptual basis in this research, some concepts of thinking used the following approach:

\section{Ratification of the Draft Criminal Code}

The discussion of a bill is carried out at two levels of discussion. The two levels of discussion as referred consist of: a. Joint Commission Talks, Legislative Board meetings, Budget Board meetings, or Special Committee meetings; and b. Level-II discussion in the Plenary Session. The discussion at the Legislative level is a decisionmaking process in a plenary meeting with activities 1). Submission of reports containing the process, general opinion of the factions, and the results

\footnotetext{
6 “Covid 19 Pandemi Menuju 200 Juta Kasus," Kompas, August 1, 2021, 1.

7 Soerjono Soekanto dan Purnadi Purbacaraka. Perihal Penelitian Hukum. (Bandung Alumni, 1979), 65
} 
of level-I discussions; 2). A verbal statement of approval or rejection from each faction and member requested by the chairman of the plenary meeting; and 3). Submission of the final opinion of the session conducted by the assigned minister. In the event that the agreement cannot be reached by deliberation to reach a consensus, then the decision is made based on the majority vote. In the event that the bill does not get mutual approval from the House of Representatives and the government, the bill may not be submitted again in the session of the House of Representatives at that time. What happened with the Draft Criminal Code was none other than an agreement between the Government and the House of Representatives to postpone (cancel) the ratification, because of the very strong pressure from student groups in various Indonesian cities, because the Draft Criminal Code to be agreed mutually is considered to still have some imperfect articles. ${ }^{8}$

\section{Rule of Law}

Since the fourth Amendment of the 1945 Constitution Year 2002, and continued with the establishment of various other laws and regulations which are carried out consistently, basically Indonesia can be called a democratic state. The embodiment of the implementation of a democratic state, among others, can be seen on the aspirations which were listened and followed up, aspirations that developed from student demonstrations against the bill that is considered problematic.

A democratic state will not be able to develop without being based on a rule of law with the core of law supremacy, justice, and benefit. According to the International Commission of Jurist, the main principles in the rule of law are:

a. The state must obey the law;

b. The government must respect individual rights under the rule of law;

c. Judges must be guided by the rule of law, protect and run without fear, impartially, and oppose any interference by the government or parties in their freedom as judges. ${ }^{9}$

Meanwhile, Jimly Asshiddiqie also formulated 12 (twelve) basic principles of the rule

\footnotetext{
8 Bayu Dwi Anggoro, Perkembangan Pembentukan Undang-Undang Di Indonesia (Jakarta: Penerbit Kanisius Press, 2014), 227-229.

9 Ibid, 44.
}

of law that apply today which are the main pillars that support the establishment of a modern state, namely:
a. Supremacy of law;
b. Equality before law;
c. Due process of law;
d. Limitation of power;
e. Independent executive organs;
f. An independent and impartial judiciary;
g. State Administrative Court;
h. Constitutional Court;
i. Human Rights Protection;
j. Democratic in nature (democratiche rechtsstaat);
k. Functioning as a means of realizing the goals of the state (welfare rechtsstaat);
1. Transparency and social control. ${ }^{10}$

\section{Covid-19 Pandemic}

After one year, Indonesia still has to work hard to overcome the Covid-19 pandemic. The national strategy in controlling Covid-19 has been and continues to be carried out through tracking, examination and treatment. In addition, it is also cultivated nationally by keeping a distance, wearing masks, and diligently washing hands with soap and running water. The Covid-19 pandemic, which was also declared and confirmed by the World Health Organization (WHO), is getting out of control. As of Friday (January 22, 2021) at 12.00 throughout Indonesia, there were 965,283 confirmed positive cases of Covid-19, with 781,147 people having recovered, and 27,453 others having died. ${ }^{11}$

Thousands of people who died in Indonesia are very diverse. Starting at the forefronts such as doctors, nurses, midwives, other medical personnel, members of the TNI and Polri, members of the wider community, regional heads, experts including criminal law expert Prof. Dr. Muladi, S.H. Through vaccination in all countries, including Indonesia, which prioritizes 1.4 million health workers. Vaccination is expected to protect

\footnotetext{
10 Umbu Ranta, Konstitusionalitas Pengajuan Peraturan Daerah (Yogyakarta: Penerbit Genta Publishing, 2016), 25-26.

" "PPKM Belum Bisa Atasi Covid-19," Kompas, January 23, 2021, 3 .
} 
them although it cannot guarantee 100 percent that they will not contract Covid-19. ${ }^{12}$

\section{DISCUSSION AND ANALYSIS}

\section{A. System Approach}

According to Sudikno Mertokusumo in his book titled Mengenal Hukum, the legal system is a unified whole of orders consisting of parts or elements that are interconnected and closely related. ${ }^{13}$

The Draft Criminal Code, as can be traced through various sources and reports in print and electronic media, has not yet reached an agreement between the government and the House of Representatives which will be ratified directly through the plenary session of the House of Representatives, or discussed in a limited manner. The United Development Party (Partai Persatuan Pembangunan)'s National Work Meeting V which was closed yesterday recommended 6 (six) things to the Government and the House of Representatives. One of them is that the two institutions were asked to immediately ratify the pending bill, including the Draft Criminal Code. ${ }^{14}$

Mardjono Reksodiputro emphasized that although the authentic text of our National Criminal Code is different from the 1918 Criminal Code (which has been amended and added), the principles of criminal law that will apply in Indonesia will not change much. Several main principles that can be used as guidance are:

1) That criminal law is also used to affirm or re-enforce basic social values of social behavior in the Unitary State of the Republic of Indonesia which is imbued with the philosophy and ideology of the state Pancasila.

2) That the criminal law as far as possible is only used in circumstances where other means of implementing social control are not or have not been implemented effectively.

${ }_{12}$ "Vaksinasi Bagi Tenaga Kesehatan Dikebut," Kompas, January 24, 2021, 3.

13 Edi Setiadi \& Kristian, Sistem Peradilan Pidana Terpadu dan Sistem Penegakan Hukum di Indonesia (Jakarta : Prenadamedia Grup, 2019), 13.

14 "PPP Minta RUU Yang Tertunda Segera Disahkan," Koran Tempo, December 16, 2019, 4.
3) In using criminal law in accordance with the two restrictions above, efforts must be made in earnest that the method is as minimal as possible to interfere with individual rights and freedoms, but without compromising the protection of the collective interests of modern Indonesian democratic society. ${ }^{15}$

The existence of the National Criminal Code is very fundamental as a national product (the Indonesian nation) itself, considering Leo Polak's assertion that the position of criminal law is a great problem, criminal law is part of the most unfortunate law, but it is an unsolved problem. ${ }^{16}$

Talking about criminal law and its applicability, one must understand the due process of law.

Criminal law is an integral part of criminal politics, where every negative act in society will be overcome by the society in various methods. When these methods cannot control the act too, then "criminal" law is used to overcome it. This is what is said that the criminal law is the "ultimum remendium" (the last cure or the last weapon). Even the politics of criminal law is not only part of criminal politics, but also part of the broader social politics as a whole. ${ }^{17}$

In criminal law, the due process of law is very fundamentally attached. The affirmation of the due process of law is formulated in the adage "nullum delicta nulla poena sine praevea lege poenali" (no offense, no crime, without a criminal law first). Based on the adage, essentially the meaning contained in the due process of law is that only the Criminal Law can qualify criminal acts and criminal threats. The establishment of criminal law is the authority of the legislative power. They are authorized to qualify criminal acts and criminal threats. ${ }^{18}$

With regard to the occurrence of criminal acts, the legal rules regarding criminal acts have a different structure from the rules regarding

15 Eddy O.S. Hiariej, Prinsip-Prinsip Hukum Pidana, Edisi Revi. (Yogyakarta: Penerbit Cahaya Atma Pustaka, 2014), xxi-xxii.

16 Sudarto, Hukum Dan Hukum Pidana (Bandung: Penerbit Alumni, 2007), 22-23.

${ }_{17}$ Teguh Prasetyo, Kriminalisasi Dalam Hukum Pidana (Bandung: Penerbit Nusa Media, 2010), 26-27.

18 Deni Setyo Bagus Yuherawan, Dekonstruksi Asas Legalitas Hukum Pidana Sejarah Asas Legalitas Dan Gagasan Pembaharuan Filsafah (Malang: Penerbit Setara Press, 2014), 70. 
how to react to those who violate them. This means that enforcement of these obligations requires an application program called the Criminal Accountability System (Gary Minda). Rules regarding criminal accountability are not standards of behavior that must be obeyed by society, but regulations on how to defend those who violate these obligations. In this connection, guilt is a determining factor for criminal accountability. Whether there is guilt or not, it is especially important for law enforcer to determine whether someone who commits a crime can be held accountable and therefore deserves to be punished. In other words, the rules of criminal law that determine the existence of a crime are primary rules, while criminal accountability is embodied in secondary rules. Therefore, from this point of view, criminal acts and criminal accountability should be separated. ${ }^{19}$

In accordance with the principles of the establishment of quality legislation (in this case the Draft Criminal Code), it is certain that it refers to the principles of establishment, content, conformity and various other aspects contained in Law Number Year 2011 Concerning the Establishment of Legislation. With regard to the fulfillment of legal principles, that legal principles are the heart of the law, so that the neglect of the importance of legal principles causes that the establishment of laws carried out by the Legislative Body is more appropriate to be called the producer of articles than legal principles. ${ }^{20}$

In responding to and reacting to the delay in the ratification of the Draft Criminal Code by the House of Representatives, the government will openly accept and re-discuss several articles that are considered problematic by various groups in society. Meanwhile, the House of Representatives has not taken a unanimous stance on what to do with the Draft Criminal Code. But what is certain is that the Draft Criminal Code has been agreed to be included in the 2019-2024 National Legislation Program, in the 2020 priority list.

19 Chairul Huda, "Dari Tiada Pidana Tanpa Kesalahan Menuju Kepada Tiada Pertanggung Jawaban Pidana Tanpa Kesalahan," in Tinjauan Kritis Terhadap Teori Pemisalahan Tindak Pidana Dan Pertanggung Jawaban Pidana (Jakarta: Penerbit Kencana Prenada Media, 2006), 18-19.

2o Satjipto Rahardjo, Hukum Dalam Jagad Ketertiban (Jakarta: Penerbit UKI Press, 2006), 123.
Since the delay or cancellation of the ratification of the Draft Criminal Code by the House of Representatives for the 2014-2019 period, the government has immediately opened itself up by accepting input from all elements of society, regarding articles that are considered problematic. As of the end of December 2019, inputs and suggestions on problematic articles have flowed and amounted to dozens of entries.

Of course, this input becomes a note and deepening of the Draft Criminal Code Drafting Team, to be followed up on whether it is accepted or rejected. An open forum by holding discussions at law faculties of state universities and private universities (accredited A), as well as with groups of criminal law observers who always follow the Draft Criminal Code, in 2019 it has not been carried out en masse. It is possible that with not too much fund, the Draft Criminal Code Drafting Team from the government together with Commission III of the House of Representatives can hold an open discussion with the Law Faculties of state and private universities (accredited A) about articles that are considered problematic, at least to synchronize perceptions.

With regard to the Draft Criminal Code which consists of 628 articles, even though it has been studied, researched, and discussed in depth and widely by involving relevant stakeholders, criminal law experts and other scientific experts, community groups, linguists, and members of the House of Representatives, it can be concluded that it is just that there is a formulation of the Draft Criminal Code article that does not fit or is contrary to other laws, which are still in effect.

To strengthen and synchronize perceptions among Ministries/Agencies towards the Draft Criminal Code, the government has opened a meeting forum with Ministries/Agencies on December 9, 2019 at the Mercure Hotel, Jalan Jenderal Gatot Subroto, Jakarta. Discussion of strategic issues in the Draft Criminal Code, with information sources Prof. Dr. Muladi, SH and Prof. Harkristuti Harkrisnowo, SH, Ph.D, Dr. Jenti Ganarsih, SH, MH as members of the Draft Criminal Code drafting team, and Prof. Dr. Markus Prasetyo, SH, LL.M.

Some of the main ideas expressed by Prof. Dr. Muladi, SH regarding the Draft Criminal Code are as follows: 
The patterns of development of criminal law in Indonesia and the related missions are as follows:

1) The structured, systematic and massive influence of the Dutch Criminal Code which encourages the Decolonialization mission;

2) The spirit of the importance of codification as a political legacy of Continental European law or "Civil Law System" strengthens the Open Recodification Mission.

3) Awareness of the aspiration of balance between social institutional morality and individual morality creates the Humanization and Democratization Mission.

4) The massive development of criminal law regulations inside and outside the Criminal Code fosters a consolidation mission.

5) Consequences of international agreements and/or the ratification of various international conventions in the era of globalization fosters the Adaptation and Harmonization Mission.

6) The development of science and theory of criminal law coupled with the development of criminal acts with modern means requires the adaptation of Actualization and Modernization Mission.

7) The results of the judicial review at the Constitutional Court which decided that several criminal law norms were considered contrary to the constitution were appreciated through the Vertical Synchronization Mission coupled with the Particularization Mission.

8) Overall, the things mentioned above are expressed and implied both in the Preamble and in the General Explanation of the law. ${ }^{21}$

From various inputs and suggestions from several stakeholders regarding the Draft Criminal Code which relate to the main tasks and functions of each stakeholder, in general there are no problems with the Draft Criminal Code which has been included in the Plenary Session of the House of Representatives in the recent past. However, there are still notes and suggestions from the Legal Bureau of the Ministry of Defense, and from the TNI-AL Legal Service, namely in article 533 of

${ }_{21}$ Muladi, "Pembaharuan Hukum Pidana Dalam RKUHP (Identifikasi Beberapa Keunggulan Sistemik RKUHP Dibandingkan Dengan KUHP Lama/Wvs" dalam FGD Kompolnas 17 Desember 2019 (Bogor, 2019). the Draft Criminal Code "An Indonesian National Armed Forces commander who refuses or ignores a request for force assistance under his orders when requested by an authorized official according to law shall be punished with imprisonment for a maximum of 4 (four) years".

The affirmation of Article 533 of the Draft Criminal Code contradicts Law Number 31 Year 1997 concerning Military Courts and Law Number 34 Year 2004 concerning the Indonesian National Armed Forces. In the implementation of Article 7 paragraph (2) point b Military Operations Other Than War (OMSP) of Law Number 34 Year 2004 concerning the Indonesian National Armed Forces, the state's political policy is absolutely necessary, in this regard through a Presidential Decree, regarding the duties and authorities:

1) Overcoming armed separatist movements;

2) Overcoming armed rebels;

3) Overcoming terrorist acts;

4) Securing border areas;

5) Securing strategic national vital objects;

6) Performing the task of world peace in accordance with foreign political policy;

7) Securing the President and Vice President and their families;

8) Empowering the defense area and its supporting forces early in accordance with the Universal Defense system;

9) Assisting in the tasks of local government;

10) Assisting the Indonesian National Police. ${ }^{22}$

Regarding this proposal from the Legal Bureau of the Ministry of Defense of the Republic of Indonesia, Prof. Dr. Muladi, S.H. says that it is necessary to reformulate article 533 of the Draft Criminal Code, clearly taking into account input and suggestions from the Legal Bureau of the Ministry of Defense, and the Indonesian National Armed Forces Babinkum. This is related to the role of the TNI in the regions which is very strategic in helping to enforce the law of public order and other emergency situations and condition in the regions.

Next from the TNI-AL Legal Service through the Head of the TNI-AL Legal Service, Admiral

\footnotetext{
${ }_{22}$ Suharyo, Dinamika Peranan TNI Dalam Penegakan Hukum Dan Kedaulatan Negara, OMSP Dan Penanggulangan Keadaan Bahaya (Yogyakarta: Penerbit Pohon Cahaya, 2016), 25.
} 
TNI Kresno Bintoro, SH, LL.M, Ph.D regarding article 548 of the Draft Criminal Code: "Everyone who uses a ship detains or commits violence or threats of violence against another ship or against people or goods that are on board a ship on the high seas or in a place outside the jurisdiction of any country with the intention of controlling people or controlling or possessing ships or goods against the law shall be punished for piracy at sea and shall be punished with a maximum sentence of 12 (twelve) years."

Suggestions and inputs on article 548 of the Draft Criminal Code, regarding the very rapid development of the use of drones, both in conditions of armed conflict (war) both in the air and at sea, need to be included in the Draft Criminal Code article on drones at sea, better known as unmanned underwater vehicle, and an unmanned vessel known as the underwater vehicle, where the country the drone came from can be identified.

In responding to these suggestions, the Drafting Team of the Criminal Code through Prof. Harkristuti Harkrisnowo, SH, LL.M, Ph.D stated that the criminal sanctions included the criminal sanctions contained in Law Number 17 Year 2008 concerning Shipping. Specifically to accommodate shipping crimes that have not been regulated in the Draft Criminal Code, at that time it was coordinated by the Maritime Security Agency (Bakamla). However, there was no follow-up. These proposals and suggestions are very useful and are the obligation of the Draft Criminal Code Drafting Team to follow up.

\section{B. Social Reaction of the Society}

The civil society movement rejects the product of legislation showing that legal issues cannot be approached only textually and dogmatically. The words in articles cannot be debated in black letters alone, as if there is no room for contemplation and questioning who the law is for. In fact, it is almost impossible to separate law from society, culture, politics and economy because inside them there are various sectors on which many people live. Law cannot be studied in an empty space, especially when society is developing very quickly thanks to digital technology, then the help of science and technology is important.

Legal reform is a matter of legal development that aims to provide affirmative justice for marginalized groups seeking justice. The history of legal development in Indonesia, as in other countries, shows its failure (Caroters, 2006, Golub 2006). The design of legal development is made top down, designed by elites without adequate knowledge about the working of law in society. The process of making laws that ignores the reality of society, even harms them, is contrary to the principle of the rule of law. Of course, it jeopardizes the future of Indonesia, the largest Islamic democratic state that the world has admired for being considered to be able to care for diversity, which turns out to be weak in implementing the rule of law. ${ }^{23}$

As a democratic rule of law, the social reaction of the society, students and various observers of criminal law is negative, they rejected the ratification of the Draft Criminal Code which is very natural, in the context of the experience of democracy in Indonesia. What would be unreasonable is that the rejection of the Draft Criminal Code, which was carried out through demonstrations, was contrary to Law Number 9 Year 1998 concerning Freedom to Express Opinions in Public.

The government is aware that there are still 14 (fourteen) problematic articles which are ready to be discussed openly. While the group of students who do not fully understand the articles in the Draft Criminal Code, as well as criminal law observers who tend to underestimate the results of the Draft Criminal Code formulation, think that there are still 24 (twenty-four) problematic articles of the Draft Criminal Code.

From searching the data and following discussions on various private television broadcasts, the explanations from the members of the Draft Criminal Code Drafting Team are actually very clear, and the Draft Criminal Code with some of its limitations needs to be reformulated. Meanwhile, those who objected to several articles in the Draft Criminal Code spoke and discussed in a spirited, serious and carefree manner, as if they were the most correct in responding to the Draft Criminal Code. In fact, their rationale is not fully harmonized with Book I of the Draft Criminal Code, as well as various laws and regulations which specifically on criminal sanctions are fully included in the Draft Criminal Code.

\footnotetext{
23 Sulistyowati Irianto, "Reformasi Hukum Untuk Siapa," Kompas, October 9, 2019, 6.
} 
Moving on from the 14 articles of the Draft Criminal Code which are still considered problematic, according to the Draft Criminal Code Drafting Team, some matters which got serious attention are: ${ }^{24}$

\section{First}

a. Article 67 of the Draft Criminal Code

The special punishment as referred to in Article $64 \mathrm{c}$ is a death penalty which is always threatened with alternatives.

b. Article 68

(1) Imprisonment is imposed for life or for a certain period of time;

(2) Imprisonment for a certain period of time is stated for a maximum of 15 (fifteen) consecutive years or a minimum of 1 (one) day, unless a specific minimum is specified.

(3) In the event that there is a choice between the death penalty and life imprisonment or there is aggravation of crime for criminal act which is sentenced to 15 (fifteen) years in prison, the imprisonment for a certain period of time may be imposed for a period of 20 (twenty) consecutive years.

(4) Imprisonment for a certain period of time may not be imposed for more than 20 (twenty) years.

Through repeated explanations of the formulation of the Draft Criminal Code, Prof. Dr. Muladi, S.H. emphasized that the death penalty is still maintained in Indonesia for certain crimes. Among several countries in the world, $60 \%$ still apply the death penalty. It is just that in the National Criminal Code in the mechanism, the death penalty can be changed to a life sentence if for 10 (ten) years of punishment the behavior of the criminal offender is good.

The death penalty controversy in Indonesia always rolls from time to time. Controversy regarding the death penalty has been submitted for a judicial review to the Constitutional Court. The petitioners who filed for judicial review were Edith Yunita Sianturi, Rani Andriani, Nyuran Sukmawan, and Andrew Dian who argued, among other things, that the death penalty is against human rights. Through a long session, the Constitutional Court issued Decision Number 2-3/PUU-V/2007 which essentially rejected the petition for a judicial review. This means that the death penalty is still valid as a positive law in Indonesia. However, there is no unanimity in making the decision. Four of the nine judges of the Constitutional Court offered different opinions regarding the death penalty. ${ }^{25}$

\section{Second}

Article 218 of the Draft Criminal Code

(1) Anyone who publicly attacks the honor or dignity of the President or Vice President shall be punished with imprisonment for a maximum of 3 (three) years and 6 (six) months or a fine of category IV at most.

(2) It does not constitute an attack on honor or dignity as referred to in paragraph (1) if the act is carried out for the public interest or for self-defense.

Regarding this provision, Prof. Harkristuti Harkrisnowo always insists that there is nothing wrong in this article. In a democratic country there are certain limits that should not be exceeded to convey criticism and suggestions. When it comes to personal insults that use words of animals, of course it has entered the realm of criminal acts. Moreover, the Draft Criminal Code also contains another article (226) which is similar regarding attack on the honor or dignity of the Heads of Friendly Countries and Representatives of Friendly Countries who are carrying out their duties in Indonesia.

\section{Third}

\section{Article 278 of the Draft Criminal Code}

Anyone who lets the poultry he raises walk in the garden or land that has been sown with seeds or plants belonging to another person shall be subject to a maximum fine of category II.

The reaction that arises against this article, because of reading the article in a hurry, is that some people do not understand what is meant in this article. It means that everyone shall know that the act of neglecting poultry that harms other people can be held accountable through fines. 


\section{Fourth}

Article 414 of the Draft Criminal Code

Everyone who openly displays, offers, broadcasts writings, or shows how to obtain contraception tools for children shall be punished with a maximum fine of category I.

The need for the stipulation of article 414 is to maintain and realize morality and ethics in children, as well as to remind that the perpetrators are trying to destroy the morality of children in Indonesia.

\section{Fifth}

\section{Article 431 of the Draft Criminal Code}

Every person who is homeless on the street or in a public place that disturbs public order shall be punished with a fine of category I at most.

Law and justice observers who are always critical of the situation in public places say that the homeless do not deserve to be fined. The state must be able to realize justice and welfare for all of its people.

Of course, in this democratic era, if all the aspirations of the Indonesian people are accommodated to produce the Draft Criminal Code like a holy book, in turn, the Indonesian National Criminal Code will not be realized. The drafters of the current generation of Draft Criminal Code are professional and democratic criminal law experts, who always accept input and suggestions from all parties. The era of democracy, the era of digitalization, the era of social media and other media that have criticized the Draft Criminal Code is the togetherness of all components of the nation so that the National Criminal Code is in accordance with the national ideals of the Indonesian nation.

\section{The Prospect Amid the Covid-19 Pandemic}

The Covid-19 pandemic has and continues to destroy the economic and health systems, and various aspects of life have also experienced the same thing, which has never happened in the modern age. Indonesia is no exception, from time to time passing 1 year of the Covid-19 pandemic, there has not been any success in minimizing the impact of the Covid-19 pandemic. Economic growth is minus $3 \%$, unemployment is getting out of control, and people's purchasing power is falling. Civil Servants and TNI/Polri must WFH (Work From Home) in a certain amount, while students must study through online learning/ lecture systems. In addition, all activities in the community including worship must go through restrictions/regulations.

Especially in government and state activities, strict health protocols must be carried out. The threat of the Covid-19 pandemic is real, very scary and should not be taken lightly. In the formation, drafting and discussion of bills in the House of Representatives which involves many people in one room, it can be likened to everyone fighting a very vicious but invisible enemy. Maintaining an effective distance to prevent the transmission of Covid-19 can sometimes be forgotten during discussions in the House of Representatives, especially at lunchtime or when drinking.

From time to time, the number of Corona-19 positive cases continues to grow. Vaccination, which is being performed on early stage, is expected to achieve successful immunity. Regarding the re-discussion of several articles in the Draft Criminal Code as demanded by opponents of the Draft Criminal Code to become National Criminal Code, there have been no significant new developments. The discussion, when carried out online, is certainly not effective. However, if the Draft Criminal Code is left alone, especially if it is not ratified until 2022, it is believed that Indonesia has lost the opportunity to have a National Criminal Code.

With the death of Prof. Dr. Muladi, S.H. as the motor for drafting the Draft Criminal Code which has been discussed in the House of Representatives, several criminal law experts from the older generation, of course, have been constrained, especially from physical aspects, and they really have to avoid crowds or gatherings. President Joko Widodo seems to have prepared the right steps for the appointment of Prof. Dr. Eddy O.S. Hiariej as Deputy Minister of Law and Human Rights of the Republic of Indonesia who has a background as a qualified criminal law expert. He is of course tasked with completing the Draft Criminal Code so that it can immediately be completed into the National Criminal Code.

The government has been open by continuing to accept various suggestions from stakeholders and the wider community for several improvements in the articles in the Draft Criminal Code. On the other hand, several factions in the House of Representatives are still consistent in 
directly ratifying the Draft Criminal Code into Criminal Code through Plenary Session.

The House of Representatives of the Republic of Indonesia officially stipulated the 2020-2024 Prolegnas (national legislative program) list. A total of 248 (two hundred and forty-eight) bills and 5 (five) open cumulative bills have been prepared. The Legislative Body has included 50 (fifty) bills in the 2020 Priority Prolegnas, including 4 (four) carry over bills from the previous period. 3 (three) carry over proposals from the government, namely the Bill on Stamps, the Bill on the Draft Criminal Code, and the Bill on Corrections. Then 1 (one) carry over bill at the proposal of the House of Representatives, namely the Bill on Amendments to Law Number 4 Year 2009 concerning Mining and Coal. ${ }^{26}$

It is necessary to deepen/elaborate on the idea that to build national legal politics, especially national criminal law, legal interpretation based on logical and systematic normative abstraction methods is no longer the only means and parameter of success to find material truths that always lead to the imprisonment of perpetrators of criminal acts. The logical abstractive interpretation method with the aim of deterrence is no longer fully justified, because it contradicts the values of Pancasila in the life of an independent, free, peaceful and eternal Indonesian nation after Indonesia's independence in 1945. Apart from this, this method is also unrealistic and has proven ineffective in realizing certainty, justice, and social benefit.

Comparative law regarding the politics of criminal law in the Netherlands and other European Union countries since the mid-20th century has shifted the retributive approach to a restorative approach in certain cases. For example, in Islam, murder cases can be resolved without punishment, namely by means of forgiveness from the victim's family and paying a diyat (ransom). This compensation model is proven to have provided adequate and balanced satisfaction to the families of victims and perpetrators of criminal acts. ${ }^{27}$

The Draft Criminal Code in this framework can be utilized as an OL because the vision and mission it carries within the framework of

26 "DPR Batal Utamakan Kualitas Dalam Pembahasan RUU," Media Indonesia, December 18, 2019, 6.

27 Romli Atmasasmita, Rekonstruksi Asas Tiada Pidana Tanpa Kesalahan (Jakarta: PT Gramedia Pustaka Utama, 2017), 93-94. systemic recodification (not just an amendment) and decolonialization process, does not include the sub-mission of consolidation and synchronization of criminal law regulations, which are scattered and often out of sync with each other, either vertically or horizontally, because since independence the Dutch colonial legacy of the Criminal Code (Wetboek van Strafrecht voor Nederlandsch Indie) has developed massively and has deviated a lot from the principles of general criminal law regulated in the codification. This development relates to both pure criminal law and administrative criminal law, including regional regulations.

As a kind of OL, the Criminal Code contains 628 articles accompanied by a vision and mission to develop a National Criminal Code with a margin of appreciation on the basis of Pancasila, the 1945 Constitution of the Republic of Indonesia, human rights and general legal principles recognized by civilized society. For this reason, even though it is difficult to completely eliminate it, systemic mitigation of the application of a retributive justice system with the nuances of retaliation against perpetrators of criminal acts must only be carried out and combined with a restorative justice system that also pays attention to the dimensions of victims of crime, the role of society, the development of behavioral science, human rights, empirical research, and the development of universal criminal law science and criminology. ${ }^{28}$

In accordance with the practice of a democratic rule of law, the people who initially rejected the Draft Criminal Code were blamed, and it is not wrong though. However, when various suggestions and inputs from members of the community on the Draft Criminal Code cannot be accommodated as a whole, of course there are strong, logical, and academically accountable rationale. Thoughts of the Members of the Drafting Team of the Draft Criminal Code are full of criticism, and it is certain that they have thought carefully to realize the National Criminal Code that is in accordance with the soul of the Indonesian nation and people. Moreover, with a series of long and very exhausting discussions and debates of the House of Representatives members who also invited legal and other experts, learned from the House of Representatives of the previous period,

${ }_{28}$ Muladi, "RKUHP Sebagai Omnibus Law," Kompas, November 27, 2019, 6. 
and had studied, criticized, and stipulated several articles that were considered problematic, to be included in the Draft Criminal Code. Regarding the Draft Criminal Code, Deputy Minister of Law and Human Rights, Prof. DR. Eddy O.S Hiariej, emphasized that the government is committed to absorbing public aspirations in discussing a number of crucial issues of the Draft Criminal Code with the House of Representatives of the Republic of Indonesia. ${ }^{29}$

As in the dynamics of a modern democratic rule of law, it is believed that the Draft Criminal Code which will be ratified into Criminal Code is not a holy book that cannot be changed by anyone. It is still wide open to all parties (Legal Standing) to file an application for judicial review of the Criminal Code to the Constitutional Court, if it turns out that the National Criminal Code is considered problematic and clearly contradicts Pancasila and the 1945 Constitution.

\section{CONCLUSION}

The demands and desires of civil society groups, human rights observers, as well as law and justice observers remain at the initial wish, that is that the government and the House of Representatives can transparently re-discuss several crucial articles in the Draft Criminal Code, so that they do not become legal problems in their implementation later.

The social reaction of certain society groups who continue to refuse the ratification of the Draft Criminal Code to become the National Criminal Code even though the government and the House of Representatives are discussing several crucial articles by taking into account the aspirations of the society members, in a democratic rule of law with a very homogeneous population, can still occur.

The prospect of the existence of the National Criminal Code in the midst of the Covid-19 pandemic is the biggest test in the establishment of law in Indonesia. The failure to ratify the Draft Criminal Code to become a National Criminal Code that has been around for 100 years naturally has the potential to use a colonial product of the Criminal Code with various versions of translation.

\section{SUGGESTION}

The re-discussion of several crucial articles in the Draft Criminal Code between the government and the House of Representatives in accordance with the aspirations of civil society groups, human rights observers, law and justice observers needs to be carried out before the Criminal Code is ratified. However, the wishes of other groups who completely reject the articles of the Draft Criminal Code are unreasonable and unacceptable.

Regarding the social reactions of various parties on behalf of certain society groups, if they continue to reject the Draft Criminal Code which will later be ratified as a national Criminal Code in a democratic rule of law, they can file an application for judicial review to the Constitutional Court of the Republic of Indonesia. Through the decision of the Constitutional Court of the Republic of Indonesia which is final and binding, of course, we can see how the national Criminal Code in the future is, whether we will continue to use the Criminal Code of colonial product for all time or use the Criminal Code of the Indonesian nation product.

Regarding the prospect of the existence of the national Criminal Code in the midst of the Covid-19 pandemic with various comprehensive and ongoing obstacles, all activities are carried out virtually. What is certain is that we hope that the Covid-19 pandemic is not the obstacle for the existence of a national Criminal Code which is characterized, has national characteristics and has a national perspective, which is not outdated by fully displaying the principles of justice, propriety, and protection of human rights based on Pancasila.

\section{ACKNOWLEDGMENT}

The researcher would like to thank the Editors, the Editorial Board, and the Reviewers of the De Jure Scientific Journal for examining and selecting the manuscript titled The Prospect of The Existence of National Criminal Code In A Democratic State In Indonesia During The Covid-19 Pandemic, so that it can and deserves to be published in the De Jure Scientific Journal. Hopefully, with the publication of this manuscript, at least it will contribute a little thought in addressing the development of national law, especially in the establishment and ratification of

\footnotetext{
29 “Isu Krusial Diprioritaskan," Kompas, June 23, 2021, 2.
} 
the Draft Criminal Code to become the National Criminal Code. Hopefully.

\section{BIBLIOGRAPHY}

Anggoro, Bayu Dwi. Perkembangan Pembentukan Undang-Undang Di Indonesia. Jakarta: Penerbit Kanisius Press, 2014.

Atmasasmita, Romli. Rekonstruksi Asas Tiada Pidana Tanpa Kesalahan. Jakarta: PT Gramedia Pustaka Utama, 2017.

Badan Pembinaan Hukum Nasional. Historisitas Hukum Pidana Indonesia (Sejarah Perkembangan Pra-Pasca Kolonial Dan Usaha Pembaharuan Hukum Pidana Nasional Di Indonesia), BPHN Kementerian Hukum Dan HAM. Jakarta, 2018.

Hiariej, Eddy O.S. Prinsip-Prinsip Hukum Pidana. Edisi Revi. Yogyakarta: Penerbit Cahaya Atma Pustaka, 2014.

Huda, Chairul.“DariTiada PidanaTanpa Kesalahan Menuju Kepada Tiada Pertanggung Jawaban Pidana Tanpa Kesalahan.” In Tinjauan Kritis Terhadap Teori Pemisalahan Tindak Pidana Dan Pertanggung Jawaban Pidana. Jakarta: Penerbit Kencana Prenada Media, 2006.

Irianto, Sulistyowati. "Reformasi Hukum Untuk Siapa." Kompas, October 9, 2019.

Muladi. "Pembaharuan Hukum Pidana Dalam RKUHP (Identifikasi Beberapa Keunggulan Sistemik RKUHP Dibandingkan Dengan KUHP Lama/Wvs,” 2019.

—. "RKUHP Sebagai Omnibus Law." Kompas, November 27, 2019.

Nurbaningsih, Enny. Problematika Pembentukan Peraturan Daerah Aktualisasi Wewenang Mengatur Dalam Era Otonomi Luas. Jakarta: Penerbit Rajawali Press, 2019.

Prasetyo, Teguh. Kriminalisasi Dalam Hukum Pidana. Bandung: Penerbit Nusa Media, 2010.

Rahardjo, Satjipto. Hukum Dalam Jagad Ketertiban. Jakarta: Penerbit UKI Press, 2006.

Ranta, Umbu. Konstitusionalitas Pengajuan Peraturan Daerah. Yogyakarta: Penerbit Genta Publishing, 2016.
Santoso, Topo. "Menjadi Negeri Tanpa KUHP Sendiri." Media Indonesia, September 23, 2019.

Sudarto. Hukum Dan Hukum Pidana. Bandung: Penerbit Alumni, 2007.

Suharyo. Dinamika Peranan TNI Dalam Penegakan Hukum Dan Kedaulatan Negara, OMSP Dan Penanggulangan Keadaan Bahaya. Yogyakarta: Penerbit Pohon Cahaya, 2016.

Yuherawan, Deni Setyo Bagus. Dekonstruksi Asas Legalitas Hukum Pidana Sejarah Asas Legalitas Dan Gagasan Pembaharuan Filsafah. Malang: Penerbit Setara Press, 2014.

"Covid 19 Pandemi Menuju 200 Juta Kasus." Kompas, August 1, 2021.

"DPR Batal Utamakan Kualitas Dalam Pembahasan RUU." Media Indonesia, December 18, 2019.

"Isu Krusial Diprioritaskan." Kompas, June 23, 2021.

"Pandemi Covid-19 Bendera Kuning Yang Makin Sering." Kompas, September 9, 2020.

"Pemerintah Dan DPR Berbeda Pendapat." Kompas, November 20, 2019.

"PPKM Belium Bisa Atasi Covid-19." Kompas, January 23, 2021.

"PPP Minta RUU Yang Tertunda Segera Disahkan." Koran Tempo, December 16, 2019.

RKUHP DPR-RI Tahun 2019, n.d.

"Vaksinasi Bagi Tenaga Kesehatan Dikebut." Kompas, January 24, 2021. 
HALAMAN KOSONG

298 Jurnal Penelitian Hukum De Jure Vol. 21 No. 3, September 2021: 285-298 